\title{
ANALISIS FINANSIAL PETERNAKAN AYAM PETELUR SUROSO FARM DESA BAKALAN KECAMATAN POLOKARTO KABUPATEN SUKOHARJO
}

\section{FINANCIAL ANALYSIS OF LAYER CHICKEN FARM AT SUROSO FARM IN BAKALAN VILLAGE POLOKARTO DISTRICT SUKOHARJO REGENCY}

\author{
Andhyka Wahyu Pambudi, Agus Setiadi, Warsono Sarengat \\ Jurusan Peternakan, Fakultas Peternakan dan Pertanian \\ Universitas Diponegoro Tembalang Semarang
}

Email: Andhykaka@gmail.com

\begin{abstract}
The purpose of this research were to know level of profit, capability of getting profit, capability of return investment, time capability of return investment, capability to know ratio of getting profit from production cost on Suroso Farm of layer chicken. The data which to be analyzed was primary data taken from interview and secondary data taken from institution. This research use kind of type financial analyzed Return On Investment (ROI), Payback Periode (PP), dan Benefit Cost Ratio (BC Ratio). The result of analyzed show rate of population Suroso Farm 35.870, ROI 68\%, PP value to return investment 1 year and $\mathrm{BC}$ ratio 2,6. That means this company Suroso Farm is feasible to be going on and profitable.
\end{abstract}

Keywords: ROI, PP, BC ratio.

\section{PENDAHULUAN}

Peternakan ayam petelur merupakan sub sektor pertanian yang potensial untuk menjadi sumber kekuatan perekonomian di Indonesia, yang selama ini selalu terpusat pada industri pemenuhan pangan melalui ayam. Permintaan pasar akan produk peternakan semakin meningkat seiring kemajuan teknologi dan peningkatan pendapatan serta pendidikan masyarakat. Kesadaran masyarakat tentang gizi yang berasal dari protein hewani semakin meningkat sehingga menuntut para peternak untuk meningkatkan produksinya. Pengembangan peternakan sangat penting untuk mendukung terpenuhinya permintaan produk peternakan yang mengandung protein hewani. Salah satu usaha peternakan untuk memenuhi kebutuhan pasar akan protein hewani adalah peternakan ayam petelur. Kegiatan pengembangan usaha peternakan ayam petelur merupakan salah satu cara dalam memenuhi kebutuhan telur di masyarakat. Hal tersebut mendorong seseorang untuk berinvestasi dalam usaha peternakan ayam petelur. Investasi dalam usaha ayam petelur tersebut cukup menjanjikan dan bersifat low risk. Analisis kelayakan suatu usaha diperlukan untuk mengkaji keberlanjutannya. 
Analisis finansial merupakan salah satu cara untuk mengetahui kondisi keuangan perusahaan. Analisis finansial dihitung dengan menggunakan investasi perusahaan, biaya-biaya yang dikeluarkan dan manfaat selama proses produksi berlangsung.

Tujuan dari penelitian ini adalah untuk mengevaluasi profitabilitas, mengevaluasi pengembalian nilai investasi dan mengevaluasi kelayakan proyek dari nilai benefit usaha ternak ayam petelur Suroso Farm. Manfaat hasil penelitian yaitu 1) bagi perusahaan sebagai informasi dan bahan pertimbangan untuk perencanaan kedepan untuk meningkatkan keuntungan agar dapat memenuhi kewajibanya baik jangka pendek maupun jangka panjang serta dapat mengembalikan investasinya. 2) bagi orang lain; sebagai gambaran kepada semua pihak yang ingin mendirikan usaha ternak ayam petelur. 3) bagi peneliti, menambah wawasan dalam manajemen peternakan ayam petelur.

\section{BAHAN DAN METODE}

Penelitian ini dilaksanakan pada Januari - Februari 2017 di "Peternakan ayam petelur Suroso Farm" Desa Bakalan Kecamatan Polokarto, Kabupaten Sukoharjo. Penelitian yang akan dilakukan dengan menggunakan metode studi kasus pada usaha peternakan ayam petelur. Metode studi kasus merupakan metode pengumpulan data atau informasi yang dilakukan secara sistematis dan mendalam yang digunakan untuk mendapatkan gambaran atau keterangan terperinci, jelas, dan data yang tepat. Penentuan lokasi dilakukan dengan pertimbangan yaitu usaha yang kontinyu, mandiri ditinjau dari skala usahanya dan data-data untuk penelitian sudah tersedia sehingga dapat dianalisis oleh peneliti.

Metode pengumpulan data dilakukan melalui wawancara dan observasi. Peneliti memperoleh informasi data melalui wawancara dengan alat bantu daftar pertanyaan (kuesioner). Sedangkan observasi yaitu proses pencatatan pola perilaku subyek (orang), obyek (benda) atau kejadian yang sistematik tanpa adanya pertanyaan atau komunikasi dengan individu yang diteliti. Data yang diperoleh berupa data primer dan data sekunder.

Data primer berupa data "Time Series" bulanan selama 3 tahun produksi kurun waktu 2014, 2015 dan 2016. Data primer meliputi identitas responden, jumlah ternak, jumlah produksi telur, biaya sanitasi dan kesehatan ternak, biaya tenaga kerja, biaya pemasaran, nilai harga penjualan telur, feses dan ayam afkir. Beberapa informasi lain mengenai sistem pemeliharaan ternak ayam petelur. Data sekunder diperoleh dari berbagai instansi atau lembaga yang terkait dalam penelitian ini. Data sekunder yang diambil meliputi topografi, monografi dan klimatologi wilayah setempat.

Data yang diperoleh kemudian ditabulasi, dihitung dan dianalisis dengan menggunakan kriteria-kriteria dalam analisis finansial usaha yaitu:

\section{Return On Investmen (ROI)}

Perhitungan ROI sesuai dengan petunjuk Purba (1997) sebagai berikut:

$$
\text { ROI }=\frac{\text { Pendapatan Bersih }}{\text { Jumlah Investasi }} \times 100 \%
$$

ROI > tingkat bunga perbankan, maka usaha tersebut layak dilaksanakan, karena dapat menghasilkan keuntungan. 
ROI < tingkat bunga perbankan, maka usaha tersebut tidak layak dilaksanakan, karena tidak dapat menghasilkan keuntungan.

2. Payback Period (PP)

Perhitungan Payback Period menurut petunjuk Riyanto (2001) sebagai berikut:

$$
\text { PP }=\frac{\text { Jumlah Investasi }}{\text { Proceed Tahunan }} \times 1 \text { tahun }
$$

Usaha tersebut dinyatakan cepat mengembalikan investasi apabila payback period lebih pendek daripada maksimum payback period yang ditentukan (3 tahun) dan akan dinyatakan lama mengembalikan investasi apabila payback period-nya lebih panjang dari maksimum yang ditentukan (3 tahun).

3. Benefit Cost Ratio (B/C Ratio) berikut:

Perhitungan BCR sesuai dengan petunjuk Kadariah (2001) sebagai

$$
\mathrm{BC} \text { ratio }=\frac{\text { PV procced }}{\text { PV Outlay }}
$$

BCR $>1$ artinya usaha tersebut menguntungkan dan layak beroperasi.

$\mathrm{BCR}<1$ artinya usaha tersebut tidak menguntungkan dan tidak layak beroperasi.

\section{HASIL DAN PEMBAHASAN}

\section{Performa Produksi Usaha Ayam Petelur Suroso Farm}

Parameter yang menjadi tolok ukur keberhasilan pemeliharaan ayam petelur diantaranya hen day, konversi pakan (FCR) dan mortalitas. Produksi pada usaha ayam petelur Suroso Farm ini dapat dijelaskan pada Tabel 1.

Tabel 1. Performa Produksi Ayam Petelur Tahun 2014-2016.

\begin{tabular}{ccccccc}
\hline \hline Tahun & $\begin{array}{c}\text { Populasi } \\
(\text { ekor })\end{array}$ & $\begin{array}{c}\text { Mortalitas } \\
(\%)\end{array}$ & $\begin{array}{c}\text { Jumlah } \\
\text { Pakan }(\mathrm{Kg})\end{array}$ & $\begin{array}{c}\text { Jumlah } \\
\text { Telur }(\mathrm{Kg})\end{array}$ & $\begin{array}{c}\text { HDP } \\
(\%)\end{array}$ & FCR \\
\hline 2014 & 35670 & 1,29 & 1416096 & 644485 & 80 & 2,19 \\
2015 & 35676 & 3,23 & 1412770 & 642971 & 80,6 & 2,19 \\
2016 & 35870 & 2,14 & 1420452 & 646467 & 83,4 & 2,19 \\
\hline
\end{tabular}

Berdasarkan Tabel 1. diketahui bahwa populasi ayam petelur pada usaha peternaan ayam petelur Suroso Farm dari tahun 2014-2016 mengalami peningkatan populasi pada tiap tahunnya meskipun angka persentase mortalitasnya mengalami kenaikan dan penurunan. Angka persentase motalitas naik dari 1,29\% menjadi 3,23\% pada tahun 2014-2015 dan kembali mengalami penurunan persentase mortalitas pada tahun 2016 menjadi 2,14\%. Aspek FCR (Feed Cost Ratio) selama tahun 2014-2016 mengalami pergerakan yang stagnan pada angka 2,19. Nilai hen day ayam petelur peternakan Suroso Farm selama kurun waktu tiga tahun berturut-turut mencapai 80; 80,6 dan 83,4. Jumlah pakan yang dihabiskan selama tiga tahun berturut-turut mencapai 1.416.096, 1.412.770, dan $1.420 .452 \mathrm{~kg}$. 
Berdasarkan FCR tahunan yang mencapai 2,19; 2,19 dan 2,19, menunjukkan bahwa efisiensi pakan yang dibutuhkan untuk meningkatkan satu satuan bobot badan masih tergolong normal dan cenderung besar. Hal inisesuai dengan Management Guide yang di terbitkan oleh Isa Brown, bahwa FCR ayam petelur pada awal bertelur hingga afkir (90 minggu) mencapai 2,09-2,20. Rasyaf (2009) menyatakan bahwa nilai FCR yang kecil menunjukkan bahwa performa yang dicapai memuaskan karena jumlah pakan yang dikonsumsi untuk menaikkan satu satuan bobot badan sedikit yang berarti penggunaan pakannya efisien. Peningkatan nilai mortalitas pada tahun 2014-2015 diduga disebabkan oleh keadaan cuaca yang buruk selama semester akhir pada tahun 2014, sehingga berakibat pada peningkatan penyakit pada ternak, sedangkan penurunan angka mortalitas pada tahun 2015-2016 diduga dikarenakan penataan menajemen kesehatan yang membaik dan penurunan intensitas cuaca yang buruk selama semester akhir tahun 2015.

\section{Biaya Produksi}

Biaya produksi adalah biaya yang berhubungan langsung dengan produksi dari suatu produk dan dipertemukan dengan penghasilan periode dimana produk itu dijual (Halim et al., 2007). Biaya produksi pada Suroso Farm berupa biaya tetap (fixed cost) dan biaya tidak tetap (Variable cost). Hal ini sesuai dengan Perwitasari et al.(2009), bahwa biaya produksi meliputi biaya tetap (biaya penyusutan, PBB dan biaya gaji pegawai) dan biaya variabel (biaya pakan, biaya kesehatan, keperluan kantor, telepon, listrik, pemeliharaan investasi gedung, DOC dan lain-lain).

Tabel 2. Biaya Tetap Tahun 2014-2016.

\begin{tabular}{|c|c|c|c|}
\hline \multirow{2}{*}{ Biaya Tetap } & Tahun 2014 & Tahun 2015 & Tahun 2016 \\
\hline & \multicolumn{3}{|c|}{ 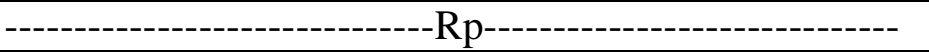 } \\
\hline $\begin{array}{l}\text { PenyusutanBangunan } \\
\text { Kandang }\end{array}$ & 108.000 .000 & 108.000 .000 & 108.000 .000 \\
\hline $\begin{array}{l}\text { Penyusutan Peralatan } \\
\text { Kandang }\end{array}$ & 15.951 .000 & 15.951 .000 & 15.951 .000 \\
\hline $\begin{array}{l}\text { Penyusutan Peralatan } \\
\text { Kantor }\end{array}$ & 771.774 & 771.774 & 771.774 \\
\hline Penyusutan Ternak & 715.200 .000 & 737.304 .000 & 765.226 .668 \\
\hline PBB & 600.000 & 600.000 & 600.000 \\
\hline Total & 876.397 .740 & 898.501 .740 & 926.424 .408 \\
\hline
\end{tabular}

Berdasarkan Tabel 2. Total biaya tetap selama tahun 2014-2016 mengalami peningkatan. Peningkatan biaya tetap dipengaruhi oleh bertambahnya nilai penyusutan ternak satiap tahunnya selama tahun 2014-2016 dikarenakan jumlah populasi ayam petelur selalu bertambah selama kurun waktu tersebut. Soekartawi (1993) menambahkan bahwa perubahan nilai biaya tetap tidak akan signifikan. Aspek biaya tetap diantaranya: penyusutan bangunan, penyusutan peralatan kandang, penyusutan peralatan kantor, penyusutan ternak dan pajak bumi bangunan. Hal ini sesuai dengan pendapat Perwitasari et al. (2009), bahwa biaya 
tetap terdiri dari biaya penyusutan dan PBB. Triana et al. (2007) menyatakan bahwa semakin tinggi skala usaha yang dikelola peternak maka semakin tinggi pula total biaya yang dikeluarkan, hal ini disebabkan untuk biaya tetap terdapat perbedaan nilai penyusutan kandang dan peralatan.

Tabel 3. Biaya Tidak Tetap Suroso Farm.

\begin{tabular}{|c|c|c|c|}
\hline \multirow{2}{*}{ Biaya Tidak Tetap } & Tahun 2014 & Tahun 2015 & Tahun 2016 \\
\hline & \multicolumn{3}{|c|}{ 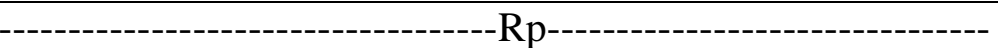 } \\
\hline Pembelian Pullet & 1.080 .000 .000 & 1.128 .000 .000 & 1.176 .000 .000 \\
\hline Pakan & 4.389 .897 .000 & 5.085 .970 .560 & 5.681 .808 .000 \\
\hline Kesehatan & 107.279.721 & 107.028.477 & 107.610.443 \\
\hline Upah Tenaga Kerja & 216.000 .000 & 240.000 .000 & 264.000 .000 \\
\hline Telepon & 2.400 .000 & 2.640 .000 & 2.904 .000 \\
\hline Listrik & 3.600 .000 & 3.900 .000 & 4.500 .000 \\
\hline $\begin{array}{l}\text { Transportasi \& } \\
\text { lain-lain }\end{array}$ & 3.900 .000 & 4.700 .000 & 4.500 .000 \\
\hline Total & 5.803.076.721 & 6.572.239.037 & 7.241 .422 .443 \\
\hline
\end{tabular}

Berdasarkan Tabel 3. dapat dilihat bahwa biaya tidak tetap terdiri dari biaya pembelian pullet, pakan, kesehatan, listrik, tenaga kerja, telepon, transportasi dan lain-lain. Hal ini sesuai dengan pendapat Mariyah (2010), bahwa biaya tidak tetap meliputi: biaya pembelian bibit ayam berupa DOC, biaya pakan, biaya obat dan vaksin, biaya pemeliharaan, biaya tenaga kerja, biaya transportasi dan biaya penunjang produksi. Parasdya et al.(2013) menyatakan biaya tidak tetap meliputi biaya pakan, biaya kesehatan, listrik, transportasi, pemasaran, rehabilitasi dan tenaga kerja lepas.

Nilai biaya tidak tetap pada Suroso Farm pada tahun 2014 sebesar Rp 5.803.076.721, pada tahun 2015 sebesar Rp 6.572.239.037 kemudian pada tahun 2016 meningkat sebesar Rp 7.241.422.443. Peningkatan biaya tidak tetap ini disebabkan karena meningkatnya harga pakan dan konsumsi pakan. Hal ini sesuai dengan pendapat Prawirakusumo (1989) bahwa pembelian pakan akan menyumbangkan nilai terbesar karena pakan sebagai kebutuhan pokok ayam petelur dan jumlahnya pun ditentukan oleh jumlah ayam yang ada. Semakin banyak ternak yang dipelihara makan pakan yang dibutuhkan dan jumlah pembelian pakan semakin besar. Aspek lain yang sangat mempengaruhi peningkatan nilai biaya tidak tetap adalah biaya pembelian pullet. Peningkatan biaya pembelian pullet dikarenakan terjadinya peningkatan harga pullet tiap tahunnya.

\section{Penerimaan}

Penerimaan utama Suroso Farm berasal dari penjualan telur utuh sedangkan penerimaan sampingan berasal dari penjualan telur retak, penjualan ayam afkir, kotoran dan karung goni. Hal ini sesuai dengan penelitian Triana et al.(2007), bahwa penerimaan dari usaha ayam ras petelur diperoleh dari produksi telur, penjualan feses, dan ayam afkir. Penerimaan total perusahaan ayam petelur Suroso Farm selama 3 tahun tertera pada Tabel 4. 
Penerimaan usaha ayam petelur per periode selama tiga tahun berturut-turut adalah Rp. 9.854.825.441; Rp. 10.489.244.002 dan Rp. 11.209.685.003. Penjualan telur utuh total penerimaan untuk tiap tahunnya mencapai Rp. 9.628.605.000; Rp. 10.246.384.000 dan Rp. 10.945.977.000. Peningkatan total penerimaan ini dikarenakan peningkatan jumlah produksi telur utuh selama tiga tahun berturutturut, yang mana produksi telur yang tinggi disebabkan oleh peningkatan populasi ayam yang dipelihara pada tahun 2014 sebesar 35.760 ekor menjadi 35.870 ekor pada tahun 2016, sehingga semakin besar populasi ayam yang dipelihara semakin tinggi penerimaan produksi yang diperoleh. Populasi ayam yang semakin banyak akan mengakibatkan semakin tinggi hasil penjualan ayam afkir. Banyaknya populasi ayam yang dipelihara juga akan berpengaruh terhadap hasil kotoran dan karung bekas pakan.

Tabel 4. Penerimaan Peternakan Suroso Farm Tahun 2014-2016

\begin{tabular}{lrrr}
\hline \hline \multirow{1}{*}{ Jenis Produk } & \multicolumn{1}{c}{ Tahun 2014 } & \multicolumn{1}{c}{ Tahun 2015 } & \multicolumn{1}{c}{ Tahun 2016 } \\
\cline { 2 - 4 } & & --------Rp------- & \\
\hline Penjualan Telur & 9.628 .605 .000 & 10.246 .384 .000 & 10.945 .977 .000 \\
Utuh & & & \\
Penjualan Teur & 25.780 .000 & 28.292 .000 & 31.032 .000 \\
Retak & & & \\
Penjualan Ayam & 170.179 .999 & 202.164 .000 & 215.220 .000 \\
Afkir & 3.200 .000 & 4.128 .520 & 4.580 .000 \\
Penjualan Kotoran & 6.520 .442 & 8.404 .002 & 12.606 .003 \\
Penjualan Karung & 9.854 .825 .441 & 10.489 .244 .002 & 11.209 .685 .003 \\
\hline Total & & & \\
\hline
\end{tabular}

Peningkatan total penerimaan dari tahun 2014-2016 sejalan dengan peningkatan total biaya produksi, khususnya pada pembelanjaan pakan yang meningkat selama 2014-2016. Wasis (1992) menyatakan bahwa penerimaan sebuah usaha selain berasal dari penjualan produk juga berasal dari aspek lain seperti penjualan kotoran dan karung. Penerimaan yang diperoleh tergantung dari jumlah produk yang dihasilkan dan harga produk. Hal ini sesuai dengan pendapat Supranto (2005) bahwa penerimaan merupakan hasil kali antara jumlah produk yang dijual dengan harga produk.

\section{Pendapatan}

Pendapatan merupakan selisih antara penerimaan dengan semua biaya yang dikeluarkan selama melakukan kegiatan usaha, dengan kata lain penerimaan dikurangi biaya produksi maka hasilnya adalah pendapatan (Candra, 2001). Besar kecilnya pendapatan secara langsung akan mempengaruhi kelangsung hidup suatu perusahaan. Pendapatan diperoleh dari selisih antara penerimaan dengan biaya produksi. Pendapatan dibagi menjadi 2 yaitu pendapatan kotor dan bersih. Menurut Triana et al. (2007) untuk menghitung pendapatan usaha perlu diketahui biaya tetap, biaya variabel dan total penerimaan. Uraian nilai pendapatan Suroso Farm tertera pada Tabel 5.

Berdasarkan data pada Tabel 5. diketahui bahwa pendapatan bersih tersebut ada setelah pendapatan dikurangi dengan pajak. Rata-rata pendapatan bersih 
(Earning After Tax) selama tahun 2014-2016 mencapai Rp 2.097.728.134; Rp 1.995.777.096 dan Rp 2.010.944.789. Laju perubahan pendapatan per tahun peternakan Suroso Farm pada tahun 2014-2015 mengalami penurunan dikarenakan terjadinya kenaikan biaya produksi sebesar $\mathrm{Rp} 769.162 .316$, yang disumbang terbesar pada kenaikan pembelian pakan dari Rp 3.100-Rp 3.600 dengan nilai total Rp 696.073.560 dan pada tahun 2015-2016 mengalami kenaikan pendapatan walaupun terjadinya kenaikan biaya produksi sebesar Rp 697.106.075 dan kenaikan total penerimaan sebesar Rp 11.209.685.003 pada tahun 2015-2016.

Tabel 5. Pendapatan Usaha Tahun 2014-2016

\begin{tabular}{lrrr}
\hline \hline \multirow{2}{*}{ Uraian } & \multicolumn{1}{c}{ Tahun 2014 } & \multicolumn{1}{c}{ Tahun 2015 } & \multicolumn{1}{c}{ Tahun 2016 } \\
\cline { 2 - 4 } & & ------- Rp--------- & \\
\hline Penerimaan & 9.854 .825 .441 & 10.489 .244 .002 & 11.209 .685 .003 \\
Biaya Produksi & 6.679 .474 .465 & 7.470 .740 .777 & 8.167 .846 .852 \\
Pendapatan Sebelum & 3.175 .350 .976 & 3.018 .503 .225 & 3.041 .838 .151 \\
Pajak (EBT) & & & \\
Pajak Penghasilan & 1.077 .622 .842 & 1.022 .726 .1299 & 1.030 .893 .353 \\
Pendapatan Setelah Pajak & 2.097 .728 .134 & 1.995 .777 .096 & 2.010 .944 .798 \\
Pendapatan Perbulan & 174.810 .678 & 166.314 .758 & 167.578 .733 \\
\hline
\end{tabular}

Munawir (2007) menyatakan bahwa pendapatan atau Earnings Before Tax (EBT) sebuah usaha akan dikurangi oleh pajak sebelum pada akhirnya menjadi pendapatan bersih atau Earnings After Tax (EAT). Soekartawi (2002) menyatakan bahwa usaha ternak akan mendapat pajak dalam setiap tahun selama usaha tersebut masih melakukan proses produksi dan mendapatkan keuntungan dari usaha yang dilakukan. Besar kecilnya pendapatan bersih yang diterima oleh peternakan ayam petelur Suroso Farm dipengaruhi oleh jumlah ayam layer, perubahan volume penjualan, total penerimaan yang diterima dan besarnya biaya produksi yang dikeluarkan. Pajak perhitungannya adalah 35\% dari jumlah pendapatan sebelum pajak (Earning Before Tax) sesuai dengan sesuai dengan pasal 17 UU No. 17 tahun 2000 tentang Pajak Penghasilan diatas Rp 200.000.000, dengan nilai $\mathrm{Rp} 3.175 .350 .976$; $\mathrm{Rp}$ 3.018.503.225 dan $\mathrm{Rp} 3.041 .838 .151$.

\section{Analisis Finansial}

Tabel 6. Hasil Analisis Finansial Perusahaan Ayam Petelur Suroso Farm

\begin{tabular}{clcc}
\hline \hline No & Metode Analisis & Satuan & Nilai \\
\hline 1 & ROI & $(\%)$ & 68 \\
2 & PP & (tahun) & 1 \\
3 & B/C Ratio & & 2,6 \\
\hline
\end{tabular}

Analisis finansial adalah analisis yang melihat suatu proyek dari sudut lembaga-lembaga atau bahan-bahan yang mempunyai kepentingan langsung dalam proyek atau yang menginvestasikan modal kedalam proyek. Analisis finansial pada perusahaan ayam Suroso Farm dinilai dengan menggunakan 
analisis finansial yaitu Return On Investmen (ROI), PP dan Benefit Cost Ratio (B/C Ratio). Alat-alat analisis tersebut dapat dihitung setelah diketahui pendapatan perusahaan. Hasil analisis finansial ditampilkan dalam Tabel 6.

Berdasarkan Tabel 6. dapat dilihat bahwa Suroso Farm menghasilkan ROI sebesar $68 \%$, PP 1 tahun dan BC Ratio sebesar 2,6 dari hasil tersebut dapat disimpulkan bahwa perusahaan menguntungkan dan layak untuk beroperasi.

Return on investment merupakan metode untuk menghitung perbandingan antara keuntungan bersih yang diterima dengan investasi yang dikeluarkan. ROI dihitung dengan membandingkan antara keuntungan rata-rata setelah pajak dengan investasi. Rata-rata pendapatan bersih Suroso Farm selama 3 tahun sebesar Rp 2.034.816.676. Berdasarkan perhitungan perusahaan ayam petelur Suroso Farm dapat dihitung ROI selama 3 tahun diperoleh nilai $68 \%$ yang berarti perusahaan dapat menghasilkan pendapatan bersih $6 \%$ dari total investasi yang ditanamkan yang artinya dalam setiap $\mathrm{Rp} 100,-$ modal atau biaya yang ditanamkan pada usaha keuntungan sebesar Rp 68,-. Nilai ROI dibandingkan dengan suku bunga deposito bank BRI sebesar 5,25\% ini berarti perusahaan ayam petelur Suroso Farm dikatakan mampu menghasilkan keuntungan dari investasi yang ditanamkan sehingga dapat dikatakan layak secara finansial. Hal ini sesuai dengan pendapat Heryadi dan Budiarsih (2013), bahwa jika nilai ROI > tingkat bunga deposito maka usaha peternakan yang dilakukan mampu menghasilkan laba dan memadai. Romadhon et al.(2012) menyatakan bahwa hasil ROI diperoleh dari persentase keuntungan yang diperoleh terhadap total modal/biaya yang dikeluarkan. Nilai ROI dapat dibandingkan dengan suku bunga deposito.

Payback period adalah suatu periode yang diperlukan untuk dapat menutupi kembali pengeluaran investasi dengan menggunakan proceed atau aliran kas neto (Riyanto, 2001). Tujuan dari payback period adalah untuk mengukur kecepatan dari suatu investasi dapat ditutup kembali dengan net cash flow dari hasil investasi tersebut (Gitusudarmo dan Basri, 2002). Total investasi atau outlay yang ditanamkan Suroso Farm sebesar Rp 2.991.600.000, proceed perusahaan pada tahun 2014 sebesar Rp 2.974.125.874, tahun 2015 sebesar Rp 2.894.278.836 dan pada tahun 2016 sebesar Rp 2.937.369.141. Perhitungan PP diperoleh nilai 1. Hasil ini menunjukkan bahwa usaha ini dapat mengembalikan investasi yang ditanamkan selama 1 tahun. Hasil ini berarti pengembalian investasi lebih cepat daripada waktu yang ditentukan yaitu 3 tahun dan dinyatakan menguntungkan. Hasil ini sesuai dengan pernyataan Husnan dan Suwarsono (2000), bahwa periode payback lebih pendek dari yang ditentukan, maka proyek dikatakan menguntungkan, sedangkan jika lebih lama proyek ditolak. Pengembalian investasi yang terlambat dalam sebuah proyek bisa menyebabkan kerugian bagi usaha tersebut. Mariyah (2010) menyatakan bahwa PP dapat diartikan sebagai jangka waktu kembalinya investasi yang telah dikeluarkan melalui keuntungan yang diperoleh dari suatu usaha.

BC Ratio adalah perbandingan antara total Benefit/Cost merupakan salah satu aspek keuangan untuk menilai kemampuan usaha dalam memperoleh pendapatan serta besarnya biaya yang dikeluarkan, dari perhitungan ini dapat dilihat tingkat pengembalian modal yang ditanamkan (Simanungkalit dan Rutkaya, 2008). Hasil analisis B/C ratio pada Suroso Farm menunjukkan bahwa 
total nilai $P V$ proceed $\mathrm{Rp}$ 7.965.407.994 dan PV Outlay Rp. 2.991.600.000. Perbandingan nilai-nilai tersebut adalah 2,6. Hasil analisis $\mathrm{B} / \mathrm{C}$ ratio yang lebih besar dari 1 menunjukkan bahwa perusahaan ayam petelur Suroso Farm mampu menghasilkan keuntungan karena mempunyai penerimaan yang lebih besar dari biaya yang harus dikeluarkan, sehingga dapat dinyatakan usaha ayam petelur layak secara finansial. Hal ini sesuai dengan pendapat Soekartawi (2002), bahwa untuk nilai $\mathrm{B} / \mathrm{C}$ ratio lebih dari 1 maka usaha tersebut dinyatakan menguntungkan atau layak untuk dikembangkan.

\section{KESIMPULAN DAN SARAN}

Penelitian mengenai analisis finansial usaha ayam petelur Suroso Farm di Desa Bakalan Kecamatan Polokarto Kabupaten Sukoharjo menghasilkan kesimpulan bahwa secara teknis pemeliharaan, tatalaksana pemeliharaan ayam petelur di Suroso Farm sudah baik serta jumlah populasi dan produksi telurnya selama tiga tahun terakhir meningkat. Berdasarkan hasil analisis finansial menghasilkan kesimpulan bahwa usaha ayam petelur Suroso Farm mampu menghasilkan keuntungan dari investasi yang ditanamkan yang ditunjukkan dengan nilai ROI sebesar $68 \%$, mampu mengembalikan investasi yang ditanamkan dalam jangka waktu yang ditentukan yang ditunjukan dengan nilai PP sebesar 1 tahun dan mempunyai nilai penerimaan yang lebih besar dari nilai investasi yang ditunjukkan dengan nilai $\mathrm{B} / \mathrm{C}$ ratio sebesar 2,6.

Saran yang dapat disampaikan oleh peneliti setelah melakukan penelitian adalah supaya peternak dapat mempertahankan manajemen kinerja yang baik agar usaha dapat berkembang lebih baik lagi.

\section{DAFTAR PUSTAKA}

Gitusudarmono dan Basri. 2002. Manajemen Keuangan. Yogyakarta: BPFE.

Halim, H. Thamrin, S dan M. Muis. 2007. Tatalaksana Pemeliharaan Dan Analisis Usaha Petrnakan Rakyat Ayam Ras Petelur Fase Layer. Jurnal Agrisistem. Vol 3 No. 1

Heryadi, Y dan L. Budiarsih. 2013. Profitabilitas Usaha Itik Pedaging di Desa Juluk Kecamatan Saronggi Kabupaten Sumenep. Hayati. Jurnal X (10). 10 Desember 2012.

Husnan dan Suwarsono. 2000. Studi Kelayakan Proyek. UPP AMP YKPN.Yogyakarta.

Kadariah. 2001. Evaluasi Proyek Analisis Ekonomi. Lembaga Penerbit Fakultas Ekonomi Universitas Indonesia. Jakarta.

Mariyah. 2010. Analisis Finansial Budidaya Ayam Petelur di Kalimantan Timur. EPP. 7 (2): 15-23. 
Munawir, S. 2007. Analisa Laporan Keuangan. Liberty, Yogyakarta.

Parasdya W., S. Mastuti dan O. E. Djatmiko. 2013. Analisis Finansial Usaha Peternakan Ayam Niaga Petelur di Kecamatan Kademangan Kabupaten Blitar. Jurnal Ilmiah Peternakan 1 (1):88-98.

Perwitasari, F.D., W. Roessali dan T. Ekowati. 2009. Analisis Profitabilitas Perusahaan Ayam Petelur PT. Suni Tama Perdana Desa Kertosari Kecamatan Singorojo Kabupaten Kendal. Jurnal Mediagro. 5 (2): 20-25. Fakultas Pertanian Universitas Wahid Hasyim. Semarang.

Prawirokusumo, S. 1989. Ilmu Usaha Tani. Edisi Pertama. Badan Penerbit Fakultas Ekonomi Universitas Gadjah Mada, Yogyakarta.

Rasyaf. 2009. Panduan Beternak Ayam Pedaging. Ed. 2. Penebar Swadaya. Jakarta.

Riyanto, B. 2001. Dasar-dasar Pembelajaran Perusahaan. Cetakan Ke-tujuh. PT BPFE. Yogyakarta.

Romadhon, H. I. Gunawan dan I. Juliani. 2012. Analisis Kelayakan Usaha Ayam Ras Petelur (Gallus sp) Studi Kasus Pada Usaha Ternak Subur Jln. Teropong KM. 2,5 Kubang Jaya kabupaten Kampar. Jurnal Penelitian Sungkai. 1 (1): $35-40$.

Simanungkalit dan Rutkaya. 2008. Inventaris Makanan Khas Toba dan Strategis Pengembanganya. Fakultas Pertanian Universitas Sumatera Utara. (Skripsi Fakultas Pertanian).

Soekartawi. 1993. Agribisnis. PT. Raja Grafindo Persada, Jakarta.

Soekartawi. 2002. Prinsip Dasar Ekonomi Pertanian. PT Raja Grafindo Persada. Jakarta.

Supranto, J. 2005. Matematika Ekonomi dan Bisnis. Ghalia Indonesia, Bogor.

Triana., A, T. Salam, dan M. Muis. 2007. Analisis Pendapatan Usaha Peternakan Ayam Ras Petelur Periode Layer Di Kecamatan Maros. Jurnal Agrisistem. 3 (1): $11-25$.

Wasis. 1992. Pengantar Ekonomi Perusahaan. Penerbit Alumni Bandung, Bandung 